\title{
RECYCLED POLYETHYLENE BONDED PARTICLE BOARD FROM PULPED AND UNPULPED GMELINA ARBOREA SAW DUST WASTES
}

\section{B.O. Ogunsile* and R. Saheed}

Department of Chemistry, University of Ibadan, Ibadan, Nigeria

E mail: bo.ogunsile@mail.ui.edu.ng; ogunsile@yahoo.com

${ }^{*}$ Corresponding author Phone: +234 8055373249

\begin{abstract}
Particle boards were prepared from saw dust wastes obtained from Gmelina aborea using polyethylene as binder. The boards were produced under three different compositional variables, namely: particles sizes (1 $\mu \mathrm{m}, 1.5 \mu \mathrm{m}$ and $2 \mu \mathrm{m})$, densities $\left(450 \mathrm{~kg} / \mathrm{m}^{3}, 550 \mathrm{~kg} / \mathrm{m}^{3}\right.$ and $\left.650 \mathrm{~kg} / \mathrm{m}^{3}\right)$ and mixing ratios ofsaw dust to polyethylene (30:70, 40:60 and 50:50). Part of the saw dust samples were chemically modified by pulping with caustic soda at $110^{\circ} \mathrm{C}$ and the effect of modification was examined on the physical and mechanical properties of the particle boards. The results showed that the chemically modified particle boards showed improved resistance to swelling and water absorption while a decrease was observed in the values of the modulus of rupture and elasticity.
\end{abstract}

\section{Keywords}

Particle board, Gmelina aborea, polyethylene, particle size, board density, mixing ratio.

\section{Council for Innovative Research}

\section{Journal: Journal of Advances in Chemistry}

Vol. 10, No. 3 


\section{INTRODUCTION}

The utilization of wood and natural fibers as a substitute to synthetic fillers such as carbon, glass or aramids for the production of particle boards is an ethically sound way of reducing the use of non - biodegradable and non - renewable resources. Woods and natural fibers because of their weight results in the formation of boards with low density and high toughness, applicable in the industrial production of window and door frames, furniture, railroad sleepers, automotive panels and upholstery, gardening items, packaging, shelves and general applications that does not require very high mechanical resistance but, low purchasing and maintenance costs [1-5]. Furthermore, the problem associated with the wearing and tearing of process equipment will be reduced as they are less abrasive than their inorganic counterpart. [5].

Wood wastes abound in Nigeria in large quantities generated on daily bases from wood processing and saw mill operations. Research finding revealed that about $45-50 \%$ of the original wood harvested in Nigeria ended up as wastes $[6,7]$. Some of these wastes are used as deep litters for poultry droppings while the majority are burnt or dump in waste sites thus constituting environmental hazards [8]. Majority of these wood wastes can effectively be used in the production of particle boards and other allied products [9].

One of the major challenges confronting the production of particle boards from woods and natural fibers is the use of formaldehyde resin as binder [10]. It has been reported that exposure to appreciable quantity of formaldehyde can cause nasal and throat congestion, burning eyes, headache and increasing risk of cancer [11-12]. The use of thermoplastics especially polyolefin have been suggested as an alternative to formaldehyde binder. Towards this end, thermoplastic boards and composites were produced from various wood and natural fibers. The production of polyethylene - wood fiber board has been reported in the literature. [13-14]. However, reported work on the use of recycled low density polyethylene (LDPE) for wood particle board production are very limited [15-17]. LDPE wastes such as water sachet are found littering almost every street in Nigeria and its recycling is a major challenge. The present study was aimed at the production of wood/plastic particle board using Gmelina arborea saw dust wastes and recycled granulated LDPE wastes as binder. The influence of process variables such as board density, mixing ratio and particle size on the physical and mechanical properties were examined using a central composite factorial design.

\section{MATERIALS AND METHODS}

\subsection{Preparation of Samples}

Samples of Gmelina arborea for the study were collected from the Forestry Research Institute, of Nigeria, FRIN, Jericho, Ibadan, Nigeria. The saw dust samples were dried and sieved to obtain the following different particle sizes: 1.00 $\mu \mathrm{m}, 1.5 \mu \mathrm{m}$ and $2 \mu \mathrm{m}$. Shredded water sachets were obtained from an MTN Waste Recycling Center, Ibadan.

\subsection{Chemical composition.}

The proportions of the chemical constituents that affect the characteristics of the plant were determined on ground samples of Gmelina arborea using standard methods as described elsewhere [18].

\subsection{Soda pulping studies}

Soda cooking liquor was prepared from a standard concentrated solution of sodium hydroxide by serial dilution with de-ionized water. The plant samples were pulped in a 10-litre electrically heated and thermostatically controlled stainless steel digester with $20 \%$ caustic soda. Saw dust samples (500g) from Gmelina arborea were weighed and charged into the digester with the required amount of chemical solution at liquor to solid ratio of 7:1. The digester was heated to the operating temperatures $\left(110^{\circ} \mathrm{C}\right)$ and the samples were pulped for 180 minutes. The resulting pulp was thoroughly washed with tap water and the pulp yield was determined gravimetrically after drying at $102^{\circ} \mathrm{C}$ to constant weight in the oven.

\subsection{Preparation of particle board and Testing}

The dried Gmelina arborea saw dust was mixed thoroughly with the appropriate amount of granulated LDPE wastes based on the specified ratio. The mixture was poured into a mold of $250 \mathrm{~mm} \times 250 \mathrm{~mm} \times 5 \mathrm{~mm}$ in dimension and then compounded at about $85^{\circ} \mathrm{C}$ for about 15 minutes at a pressure of about $1.23 \mathrm{~N} / \mathrm{mm}^{2}$. The water absorption (WA) characteristic of the boards was determined manually based on the difference between the weight of test specimen soaked for 24 hours and the oven dry weight test specimen. The thickness swelling (TS) was based on the difference in their thickness. The bending modulus of elasticity (MOE) and modulus of rupture (MOR) were estimated from the load deflection curves at peak according to ASTM standard D 1037-96a (1998) [19]. A Scanning Electron Microscope (SEM) (Aspex 3020) was used to examine the Gmelina arborea surfaces of the particle board.

\subsection{The central composite factorial design}

The central composite factorial design was employed to evaluate and quantify the effect of the operational variables on the pulp yields and residual lignin. The effect of the variables were quantified more precisely by choosing part of the experimental results and grouping them to form a first order full factorial design, with variables at two levels $\left(2^{3}\right)$. Using this design, some of the experimental data were fitted to a first order polynomial regression equation as implemented in the "SPSS" statistical package. Individual and second order interaction influences over the response surface of the independent variables were evaluated [20]

The mathematical model was: 


$$
Y=a_{0}+a_{1} X_{1}+a_{2} X_{2}+a_{3} X_{3}+a_{12} X_{1} X_{2}+a_{13} X_{1} X_{3}+a_{23} X_{2} X_{3}
$$

The response variable $Y$ represents the physical (WA and TS) and mechanical properties (MOR and MOE). The independent variables $X_{1}, X_{2}$ and $X_{3}$ correspond to the $B D, M R$ and PS respectively. The ranges of values for each independent variable were: $\mathrm{BD}, 450,550$ and $650 \mathrm{~kg} / \mathrm{m}^{3}$, MR, 30:70, 40:60 and 50:50 and PS, 1.0, 1.5 and $2.0 \mu \mathrm{m}$.

The values of the independent variables were normalized from -1 to +1 by using the equation:

$$
X_{n}=2(\overline{X-X}) /\left(X_{\max }-X_{\min }\right)
$$

Where $\bar{X}_{n}$ is the normalized value of $B D, M R$ and $P S, X$ is the absolute experimental value of the variable, $X$ is the mean of all the experimental values for the variable in question, $X_{\max }$ and $X_{\min }$ are the maximum and minimum values respectively of the variable.

\section{RESULTS AND DISCUSSION}

\subsection{Proximate composition}

The chemical composition of the Gmelina arborea is as tabulated in Table 1. The result indicated that the Gmelina arborea contained $61.22 \%$ cellulose and $20.0 \%$ lignin. These values are moderate and good for typical fiberboard making [21]. The cellulose is a measure of board yield and density while the lignin content acts like a binder between fibers in the adhesion process [22]. The value of the aqueous extractives, i.e. cold and hot water solubility, which represents the amount of tannins, gums, sugar, colouring matter and starches, is moderate and suitable. The level of fungi attack ( $1 \%$ caustic soda solubility) is low and the ash content is tolerable and will not pose any problem in the production process.

Table 1: Chemical composition of Gmelina arborea saw dust

\begin{tabular}{lc}
\hline Parameter & Amount (\%) \\
\hline Ash & 5.04 \\
Lignin & 20.00 \\
Cellulose & 61.22 \\
$1 \% \mathrm{NaOH}$ solubility & 4.60 \\
Cold water solubility & 2.05 \\
Hot water solubility & 6.27 \\
\hline
\end{tabular}

\subsection{Physical properties of the board}

The result of the thickness swelling and water absorption properties of the pulped and unpulped boards is given in Table 2. As observed from the table, the thickness swelling and water absorption was greatly affected by the soda pulping of the Gmelina arborea saw dust. The low saturated mass gain and the boards great improvement in their resistance to water is the major benefits of the pulping treatment. The boards made from unpulped samples absorbed more water significantly than the pulped samples. The percentage difference in the amount of water absorb was more than $90 \%$. Thus pulping reduces swelling and water absorption of the board. Apart from the hydrophilicity developed by the pulping treatment, the low thickness swelling and water absorption is also an indication of good fiber/matrix adhesion. Alkali treatment removes lignin and hemicellulose from the surface of natural fibers [23], thus making the pulp fibers to collapse and glue more tightly together. Thus, the amount of voids is reduced and internal swelling and water absorption is minimized [24].

\subsection{Mechanical properties of the board}

The values of the MOR and MOE of the unpulped board as shown in Table 3 were comparably higher than the board made from the pulped samples. This may be attributed to the pulping treatment. During pulping, lignin and part of the hemicelluloses that bind the fibers together were removed leading to reduction in rigidity and subsequent reduction in resistance to static bending. Loss in strength occurred during the 
Table 2: Physical properties of the Gmelina arborea / LDPE boards

\begin{tabular}{|c|c|c|c|c|c|c|}
\hline \multirow[t]{2}{*}{ Variables } & \multicolumn{3}{|c|}{ WaterAbsorption (\%) } & \multicolumn{3}{|c|}{ Thickness swelling (\%) } \\
\hline & $\begin{array}{l}\text { Unpulped } \\
\text { sample }\end{array}$ & $\begin{array}{l}\text { Pulped } \\
\text { sample }\end{array}$ & $\begin{array}{c}\% \\
\text { Difference }\end{array}$ & $\begin{array}{l}\text { Unpulped } \\
\text { sample }\end{array}$ & $\begin{array}{l}\text { Pulped } \\
\text { sample }\end{array}$ & $\%$ Difference \\
\hline $\mathrm{BD}_{1}\left(1000 \mathrm{Kg} / \mathrm{m}^{3}\right)$ & 1.17 & 0.056 & 95.26 & 0.22 & 0.09 & 56.62 \\
\hline $\mathrm{BD}_{2}(1050 \mathrm{Kg} / \mathrm{m} 3)$ & 0.75 & 0.039 & 94.83 & 0.15 & 0.10 & 33.83 \\
\hline $\mathrm{BD}_{3}(1100 \mathrm{Kg} / \mathrm{m} 3)$ & 0.80 & 0.052 & 93.48 & 0.14 & 0.10 & 26.85 \\
\hline $\mathrm{MR}_{1}(30 / 70)$ & 1.27 & 0.057 & 95.52 & 0.17 & 0.10 & 41.15 \\
\hline $\mathrm{MR}_{2}(35 / 65)$ & 0.79 & 0.044 & 94.36 & 0.14 & 0.10 & 30.38 \\
\hline $\mathrm{MR}_{3}(40 / 60)$ & 0.67 & 0.046 & 93.22 & 0.19 & 0.09 & 50.82 \\
\hline $\mathrm{PS}_{1}(1.0 \mathrm{um})$ & 0.59 & 0.027 & 95.51 & 0.16 & 0.09 & 42.13 \\
\hline $\mathrm{PS}_{2}(1.5 \mathrm{um})$ & 0.88 & 0.043 & 95.06 & 0.20 & 0.10 & 51.18 \\
\hline $\mathrm{PS}_{3}(2.0 \mathrm{um})$ & 1.25 & 0.077 & 93.89 & 0.14 & 0.10 & 28.19 \\
\hline
\end{tabular}

Table 3: Mechanical properties of the Gmelina arborea / LDPE boards

\begin{tabular}{|c|c|c|c|c|c|c|}
\hline \multirow[t]{2}{*}{ Variables } & \multicolumn{3}{|c|}{ Modulus of Rupture $\left(\mathrm{N} / \mathrm{mm}^{2}\right)$} & \multicolumn{3}{|c|}{ Modulus of Elasticity $\left(\mathrm{N} / \mathrm{mm}^{2}\right)$} \\
\hline & $\begin{array}{l}\text { Unpulped } \\
\text { sample }\end{array}$ & $\begin{array}{l}\text { Pulped } \\
\text { sample }\end{array}$ & $\%$ Difference & $\begin{array}{l}\text { Unpulped } \\
\text { sample }\end{array}$ & $\begin{array}{l}\text { Pulped } \\
\text { sample }\end{array}$ & $\%$ Difference \\
\hline $\mathrm{BD}_{1}\left(1000 \mathrm{~kg} / \mathrm{m}^{3}\right)$ & 0.36 & 0.240 & 33.33 & 81.11 & 46.80 & 42.30 \\
\hline $\mathrm{BD}_{2}\left(1050 \mathrm{~kg} / \mathrm{m}^{3}\right)$ & 0.43 & 0.190 & 55.81 & 146.84 & 65.10 & 55.67 \\
\hline $\mathrm{BD}_{3}\left(1100 \mathrm{~kg} / \mathrm{m}^{3}\right)$ & 0.54 & 0.260 & 51.85 & 112.91 & 55.94 & 50.46 \\
\hline $\mathrm{MR}_{1}(30 / 70)$ & 0.39 & 0.200 & 48.72 & 90.40 & 43.27 & 52.13 \\
\hline $\mathrm{MR}_{2}(35 / 65)$ & 0.42 & 0.250 & 40.48 & 153.50 & 76.60 & 50.10 \\
\hline $\mathrm{MR}_{3}(40 / 60)$ & 0.51 & 0.250 & 50.98 & 97.00 & 47.96 & 50.56 \\
\hline $\mathrm{PS}_{1}(1.0 \mathrm{um})$ & 0.52 & 0.300 & 42.31 & 130.91 & 63.68 & 51.36 \\
\hline $\mathrm{PS}_{2}(1.5 \mathrm{um})$ & 0.45 & 0.250 & 44.44 & 112.03 & 58.04 & 48.19 \\
\hline $\mathrm{PS}_{3}(2.0 \mathrm{um})$ & 0.35 & 0.140 & 60.00 & 97.92 & 46.12 & 52.90 \\
\hline
\end{tabular}

chemical and heat treatment of the Gmelina arborea saw dust. [25, 26]. Thus, the pulping treatment did not enhance the mechanical properties of the Gmelina arborea LDPE boards.

\subsection{SEM Analysis}

Analysis of the morphological features of fracture surfaces of the recycled LDPE / Gmelina arborea board taking at different magnification is shown in Figure 1. Scanning Electron Micrograph is important for observing the surface morphology of fiber/matrix. The result showed good adhesion of Gmelina saw dust with the LDPE matrix.

\subsection{The factorial design}

Experiments $1-15$ of Tables 4 and 5 allowed the calculation of different parameters in the regression equations $a_{i}$ and $a_{i j}$. These were subsequently subjected to a $\mathrm{T}$ - test to check their significance at $90 \%$ confidence level. The central point of the design corresponds to the following reaction conditions:

Board Density, $\mathrm{BD}=1050 \mathrm{~kg} / \mathrm{m}^{3}$ 


\section{《㫨)}

Mixing Ratio, $M R=60: 40$

Particle Size, PS $=1.5 \mu \mathrm{m}$

The coefficients of the model equations and the statistical parameters establishing their validity are summarized in Table 6 and 7 to the pulped and unpulped samples respectively. The dependent variables (i.e. thickness swelling, water absorption, modulus of rupture and elasticity) were related to the independent variables through the equations $3-10$.

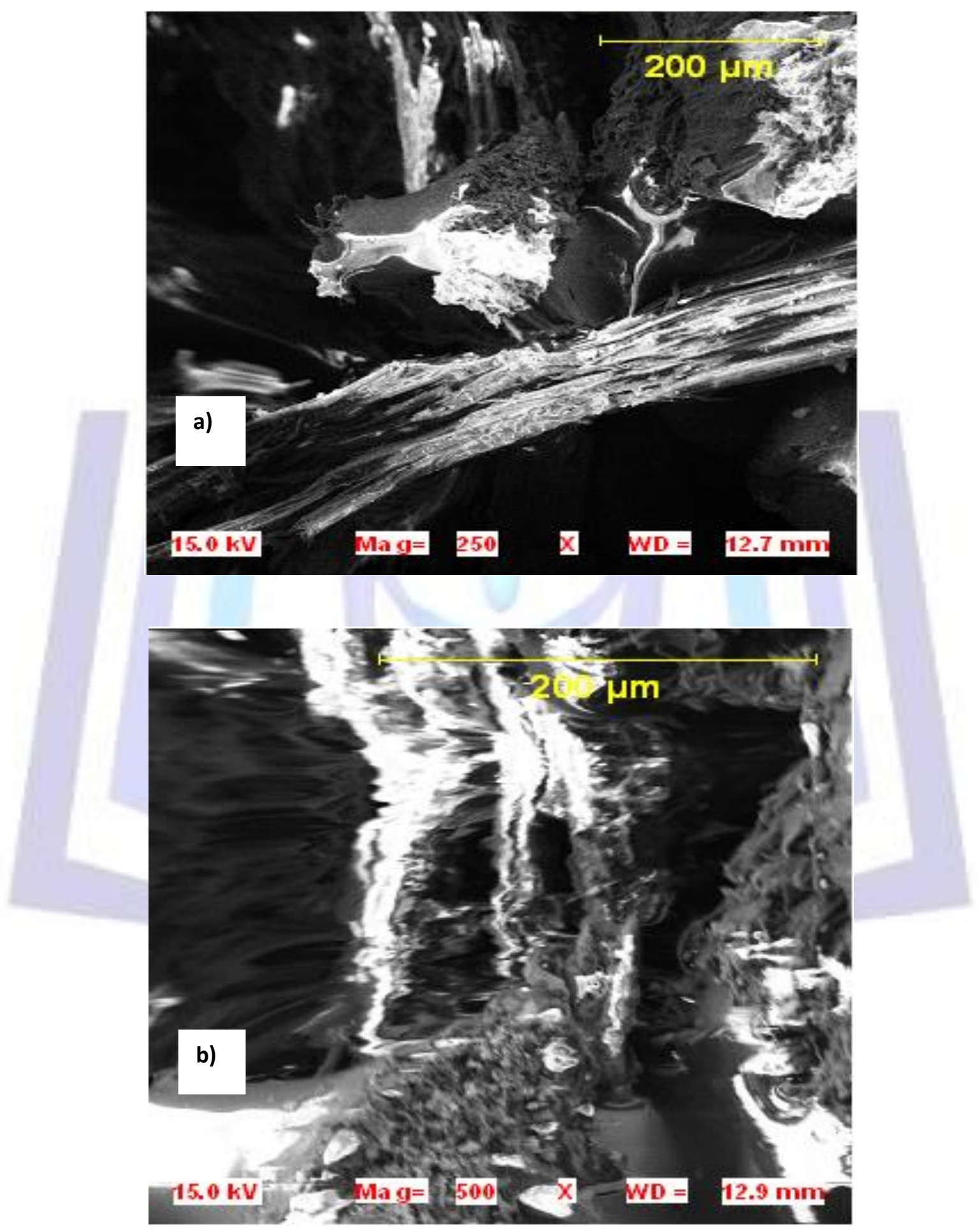

Figure 5: SEM images of the LDPE bonded particle board at (a) x250 and (b) x500 magnification 
Table 4: Experimental design and result for board made from pulped saw dust

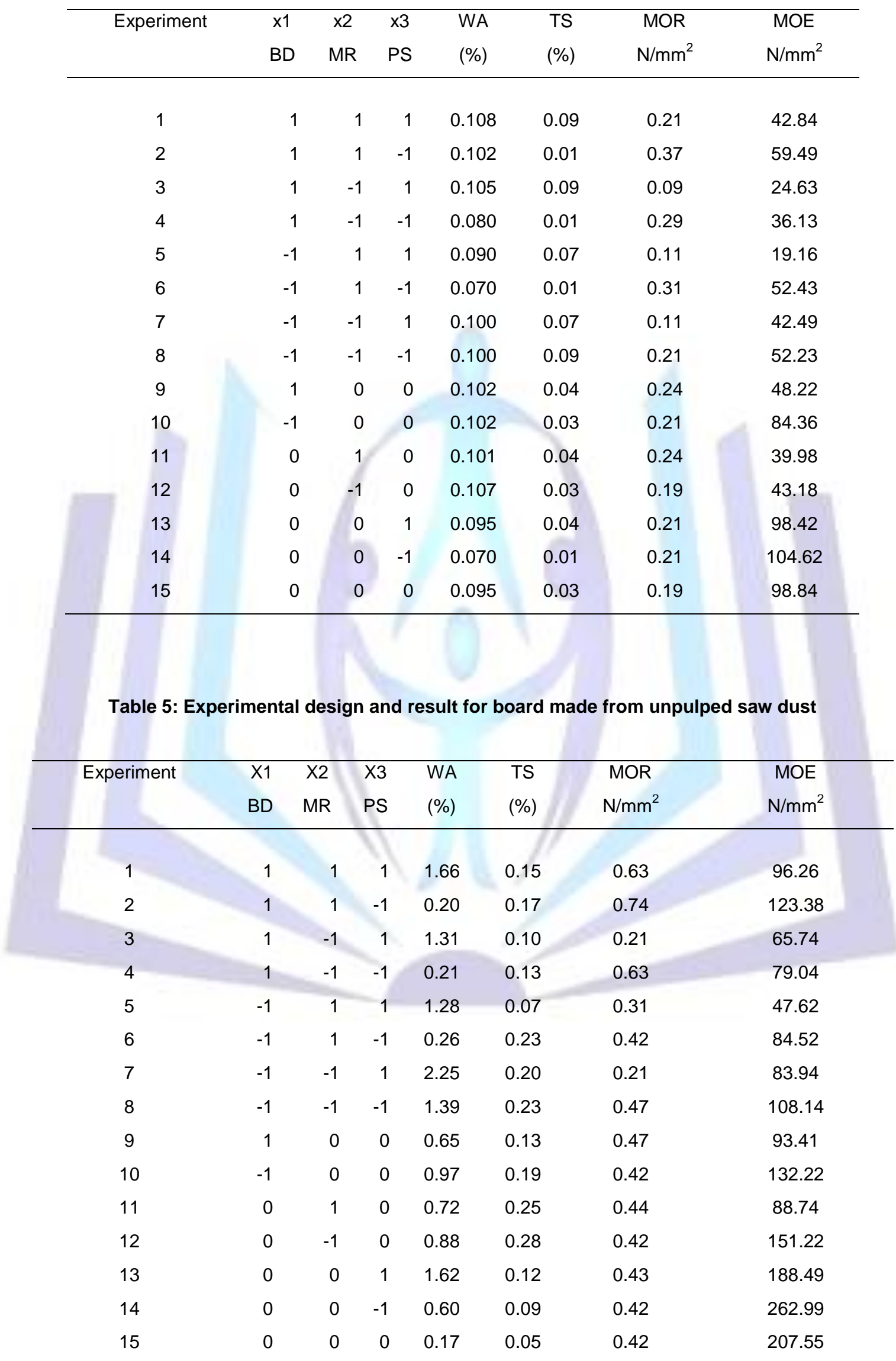


Table 6: Signicative regression parameters for board made from pulped Gmelina arborea saw dust

\begin{tabular}{|c|c|c|c|c|}
\hline & TS & WA & MOR & MOE \\
\hline$a_{0}$ & 0.022 & 0.096 & 0.21 & 88.36 \\
\hline$a_{1}$ & $(-0.005)$ & $(0.003)$ & $(0.025)$ & $(-3.94)$ \\
\hline$a_{2}$ & $(-0.007)$ & $(-0.002)$ & 0.035 & (1.52) \\
\hline$a_{3}$ & 0.026 & 0.008 & -0.066 & $(-7.74)$ \\
\hline$a_{12}$ & $(0.01)$ & 0.008 & $(0.012)$ & (8.09) \\
\hline$a_{13}$ & 0.017 & $(0.001)$ & $(-0.007)$ & $(1.86)$ \\
\hline$a_{23}$ & $(0.01)$ & $(0.00)$ & $(-0.008)$ & $(-3.59)$ \\
\hline$a_{11}$ & $(0.015)$ & $(0.05)$ & $(0.009)$ & -19.45 \\
\hline$a_{22}$ & $(0.015)$ & $(0.07)$ & $(-0.001)$ & -44.16 \\
\hline$a_{33}$ & $(0.00)$ & $(-0.014)$ & $(-0.006)$ & 15.78 \\
\hline \multicolumn{5}{|c|}{$\begin{array}{l}\text { Values in parenthesis are not significant } \\
\text { able 7: Signicative regression parameters for board made from } \\
\text { unpulped Gmelina arborea saw dust }\end{array}$} \\
\hline & TS & WA & MOR & MOE \\
\hline$a_{0}$ & 0.64 & 0.146 & 0.423 & 192.4 \\
\hline$a_{1}$ & -0.21 & $(-0.024)$ & 0.085 & $(0.14)$ \\
\hline$a_{2}$ & -0.19 & $(-0.07)$ & 0.06 & $(-4.76)$ \\
\hline$a_{3}$ & 0.55 & $(-0.21)$ & -0.089 & (17.6) \\
\hline$a_{12}$ & 0.31 & $(0.028)$ & $(0.06)$ & (16.85) \\
\hline$a_{13}$ & $(0.085)$ & $(0.017)$ & $(-0.02)$ & (2.59) \\
\hline$a_{23}$ & $(0.065)$ & $(-0.015)$ & $(0.057)$ & $(-3.32)$ \\
\hline$a_{11}$ & $(0.058)$ & $(-0.01)$ & $(0.022)$ & -75.78 \\
\hline$a_{22}$ & $(0.048)$ & 0.095 & $(0.007)$ & -68.62 \\
\hline$a_{33}$ & 0.36 & $(-0.065)$ & (0.002) & 37.14 \\
\hline
\end{tabular}

Values in parenthesis are not significant

Equations 3 to 6 were obtained for boards made from pulped samples while equations 7 to 10 were for the unpulped samples.

$$
\begin{aligned}
& T S=0.022+0.026 X_{3}+0.017 X_{1} X_{3} \\
& W A=0.096+0.008 X_{3}+0.008 X_{1} X_{3}+0.014 X_{3} X_{3} \\
& M O R=0.21+0.035 X_{2}+0.066 X_{3}
\end{aligned}
$$




$$
\begin{aligned}
& M O E=88.36-19.45 X_{1} X_{2}-44.16 X_{2} X_{2}+15.78 X_{3} X_{3} \\
& T S=0.64-0.21 X_{1}-0.19 X_{2}+0.55 X_{3}+0.31 X_{1} X_{2}+0.36 X_{3} X_{3} \\
& W A=0.146+0.095 X_{2} X_{3} \\
& M O R=0.423+0.085 X_{1} 0.06 X_{2}-0.089 X_{3} \\
& M O E=192.4-75.78 X_{1} X_{2}-68.62 X_{2} X_{2}+37.14 X_{3} X_{3}
\end{aligned}
$$

Values calculated from the respective polynomial equations above were plotted with the experimental results for the different response variables as shown in Figures 2-5.

Equations (3) and (7) show the variations of thickness swelling with changes in the independent variables based on pulped and unpulped samples respectively. Equation (3) based on pulped samples showed that only the PS had significant influence on the thickness swelling. There were, however, significant variations between BD and PS. On the other hand, all the process variables have significant influence on thickness swelling, besides the significant interaction between $\mathrm{BD}$ and MR according to equation 7. While equation 3 failed to predict the thickness swelling to a reasonable degree of certainty, equation 7 predicted it with errors less than $10 \%$ at $90-95 \%$ confident level (Figure 2). The water absorption of the pulped Gmelina arborea board was predicted by equation 2 with errors less than $40 \%$ while equation 8 failed to do the same for the unpulped board sample (Figure 3). According to equation 2, water absorption depended majorly on the particle size and interaction between the particle size and board density.

Equations 3 and 9 predicted the modulus of rupture for the pulped and unpulped board with errors less than 30 and $35 \%$ respectively. The correlation graph is shown in Figure 4. Both equations showed that PS and MR had significant influence on the modulus of rupture of the boards. The modulus of elasticity was well predicted by equation 5 with errors less than $22 \%$ (Figure 5) and with significant effects from all the process variables. Equation 10 failed to predict the modulus of elasticity.

The inability of some of the equations to predicts some properties of the board may be due to some inconsistencies in the conditions under which the experiment was carried out such as different relative humidity and the erratic power supply.

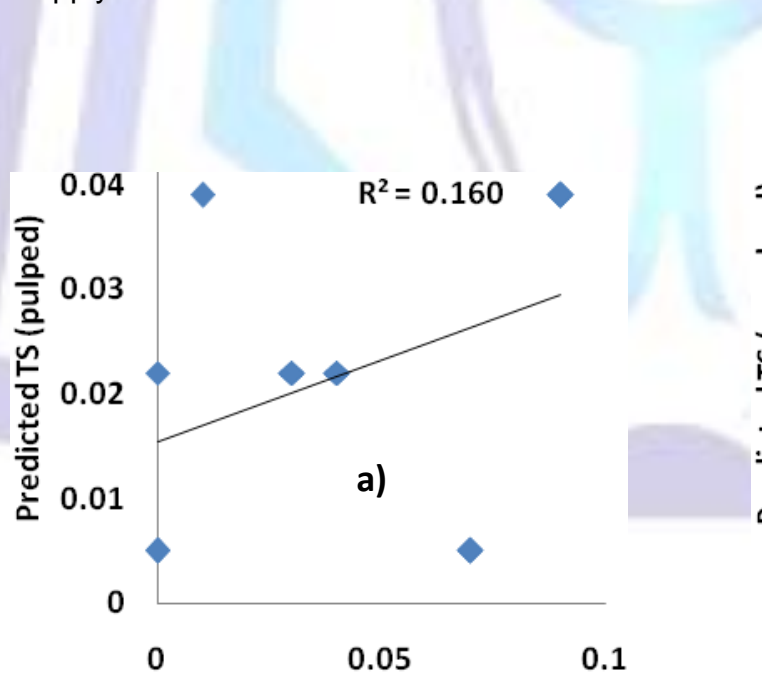

Experimented TS (pulped)

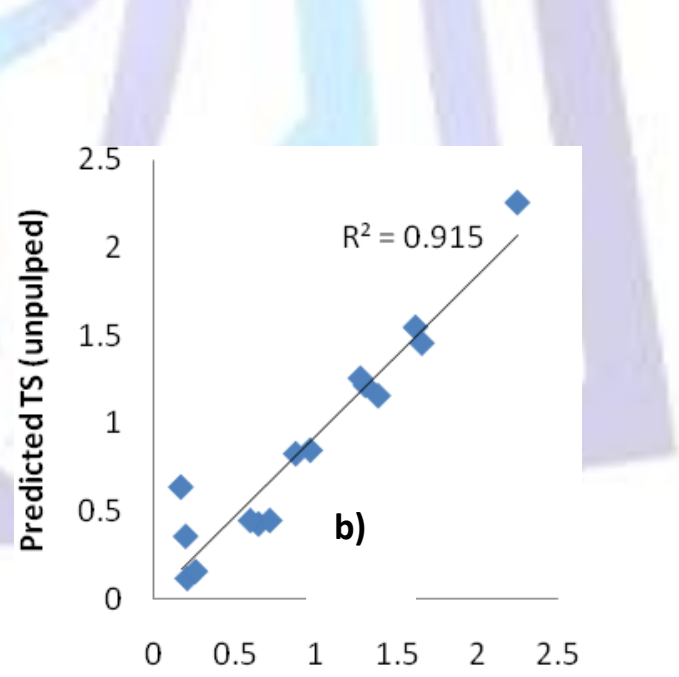

Experimented TS (unpulped)

Figure 2: Correlation between predicted and experimental values of thickness swelling of (a) pulped and (b) unpulped board 

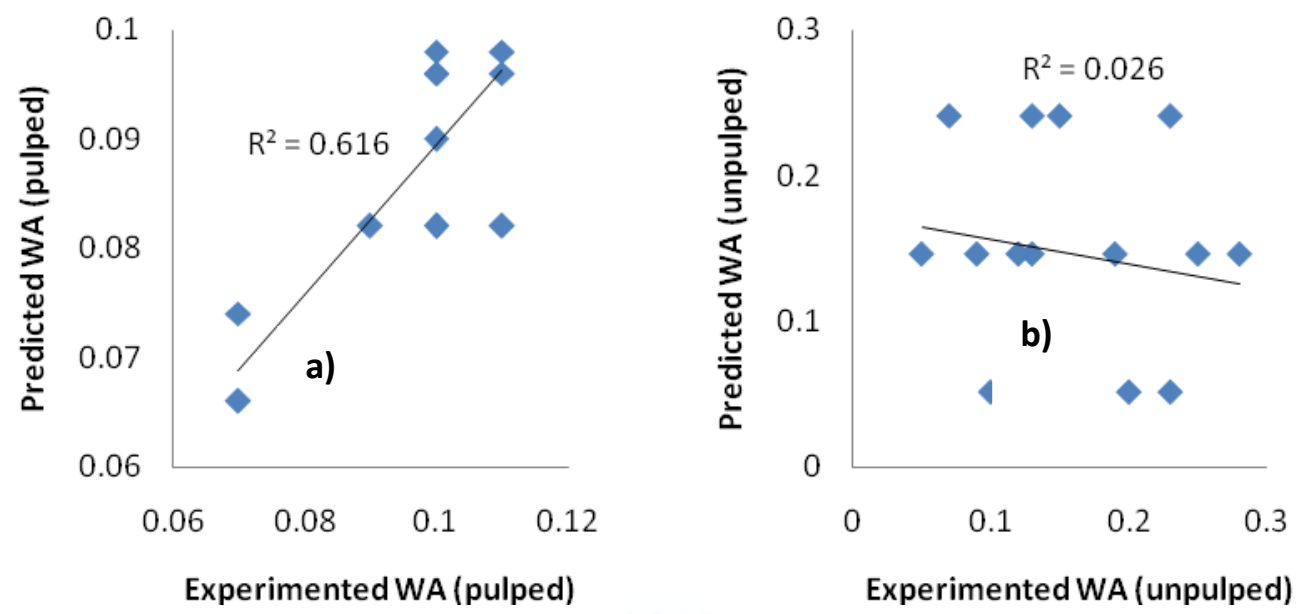

Figure 3: Correlation between predicted and experimental values of water absorption of (a) pulped and (b) unpulped board

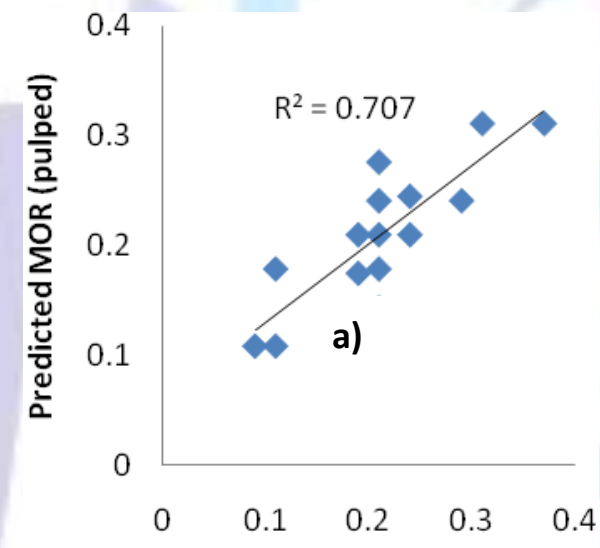

Experimented MOR (pulped)

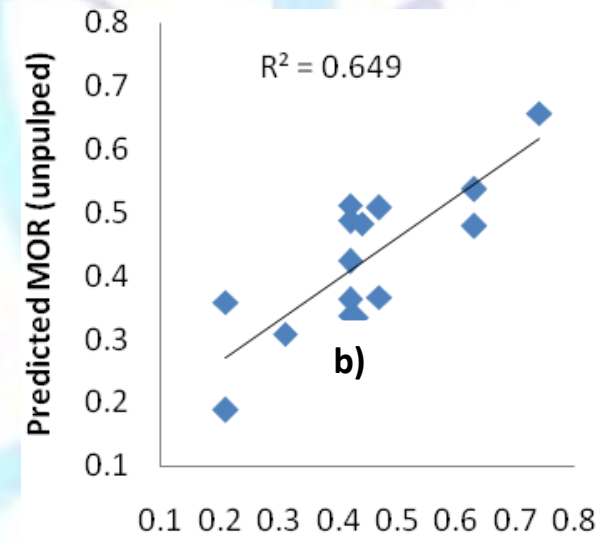

Experimented MOR (unpulped)

Figure 4: Correlation between predicted and experimental values of modulus of rupture of (a) pulped and (b) unpulped board

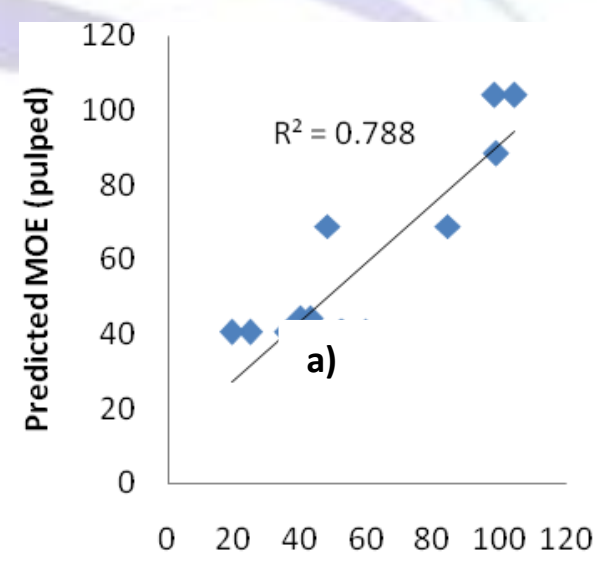

Experimented MOE (pulped)

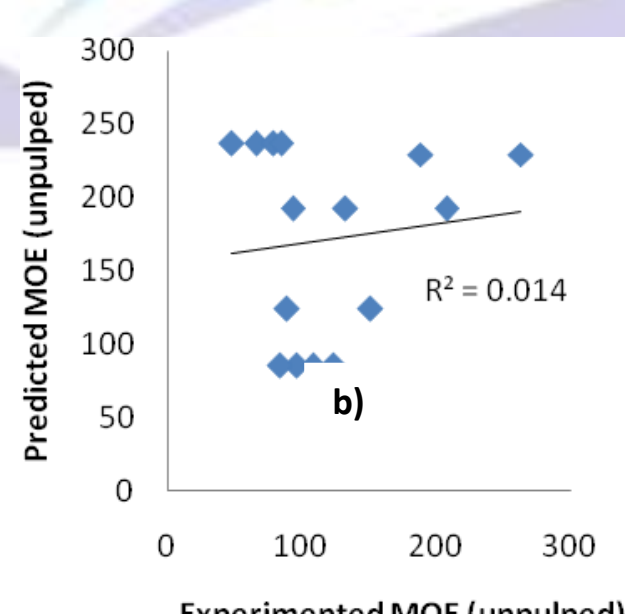

Experimented MOE (unpulped)

Figure 5: Correlation between predicted and experimental values of modulus of elasticity of (a) pulped and (b) unpulped board 


\section{CONCLUSIONS}

Particle boards of size $250 \mathrm{~mm} \times 250 \mathrm{~mm} \times 5 \mathrm{~mm}$ were made from soda pulped and unpulped Gmelina arborea using recycled LDPE as binder. The proximate composition of Gmelina arborea saw dust was suitable for the production of the particle boards. Boards made from unpulped samples absorbed more water significantly than the pulped samples. Thus pulping reduces swelling and water absorption of the board. The values of the modulus of rupture and elasticity of the unpulped board were comparably higher than those from the pulped samples. The central composite factorial design predicted the thickness swelling of unpulped board with errors less than $10 \%$ at $90-95 \%$ confident level.

\section{ACKNOWLEGDEMENTS}

The authors wish to aknowledge the technical assistant rendered by Mr Aina of FRIN, Nigeira.

\section{REFERENCES}

[1] Bataille, P., Ricard, L. and Sapieha S.( 1989) Effects of cellulose fibers in polypropylene composites. Polym Compos., 10: 103-108.

[2] Rozman, H.D., Lai, C.Y., Ismail, H. and Mohd Ishak, Z.A. (2000) The effect of coupling agents on the mechanical and physical properties of oil palm empty fruit bunch polypropylene composites. Polym Int., 49: 1273-1278.

[3] Carroll, D.R., Stone, R.B., Siringano, A.M., Saindon, R.M., Gose, S.C. and Friedman, M.A. (2001) Structural properties of recycled plastic/sawdust lumber decking planks. Res. Cons. Recycl. 31: 241-51.

[4] Netravali, A.N. and Chabba, S. (2003) Composites get greener. Mater. Tod. 6: 22-26.

[5] La Mantia, F.P. and Morreale, M. (2011) Green composites: A brief review Composites: Part A 42: 579-588

[6] Ajayi, B. (2004). Reaction of cement-bonded composites from Gmelina arborea and Leucaena leucocephala to water treatment. Nigerian Journal of Forestry, 34(1-2): 125-131.

[7] Babayemi, J.O. and Dauda, K.T. (2009). Evaluation of the solid waste generation categories and disposal options in developing countries: a case study of Nigeria. J. Appl. Sci. Environ. Manage. 13 (3): 83-88

[8] Aina, O.M. (2006) Wood waste utilization for energy generation. Proceedings of the Intl Conference on Renewable Energy for Developing Countries 8pp

[9] Ogunsanwo, O. Y. (2001) Effective Management of Wood Waste for Sustainable Wood Utilization in Nigeria In: Popoola, L. et al - editors, Proceeding of the 27th Annual Conference of Forestry Association of Nigeria Abuja, FCT 17-21, Sept., pp 225-234

[10] Rokiah, H., Siti Hazneza, A. H., Othman, S., Norli, I., Hakimi, I. M., Hasnah, M. J. and Salmiah,U. (2009). Extractable formaldehyde from waste medium density fibreboard, Journal of Tropical Forest Science, 21(1): 2533.

[11] Hauptmann, M., Lubin, J.H., Stewart, P.A., Hayes, R.B. and Blair, A. (2003) Mortality from lymphohematopoietic malignancies among workers in formaldehyde industries, Journal of the National Cancer Institute, 95 (21): 16151623.

[12] Beane, F. L., Blair, A., Lubin, J.H. ... (2009) Mortality from lymphohematopoietic malignancies among workers in formaldehyde industries: The National Cancer Institute Cohort. Journal of the National Cancer Institute 2009; 101(10):751-761.

[13] Joseph. K. and Thomas, S. (1993) Dynamic mechanical properties of short sisal fiber reinforced low density polyethylene composites, Journal of Reinforced Plastics and Composites, 12(2): 139-55.

[14] Pothana, L. A., Oommenb, Z. and Thomas, S. (2003) Dynamic mechanical analysis of banana fiber reinforced polyester composites. Composites Science and Technology 63(2): 283-93.

[15] Han, T.H and Kwon, J H. (2009) Physical and mechanical properties of composite panel manufactured from wood particle and recycled polyethylene. Journal of the Korean Wood Science and Technology 37 (4): 340-348.

[16] Atuanya, C. U.*, Ibhadode, A. O. A. and Igboanugo, A. C.(2011) Potential of using recycled low-density polyethylene in wood composites board, African Journal of Environmental Science and Technology, 5 (5): 389 396.

[17] Agunsoye, J.O. and Aigbodion, V.S. (2013) Bagasse filled recycled polyethylene bio-composites: Morphological and mechanical properties study, Results in Physics 3: 187-194.

[18] Omotoso, M.A. and Ogunsile, B.O. (2009) Fiber and chemical properties of some Nigerian grown Musa species for pulp production. Asian Journal of Material Science. 1(1): 14-21. 
[19] ASTM (1998). Standard Test Methods for Evaluating Properties of Wood-Base Fiber and Particle Panel Materials. ASTM D 1037 - 96a.The American Society for Testing and Materials, Philadelphia, Annual Book of ASTM Standards, Vol. 04. 09 Wood.

[20] Aknazarova, S. and Kafarov, V. (1982). Experiment Optimization in Chemistry and Chemical Engineering. Mir Publishers, Moscow.

[21] Martín-Sampedro, R., Rodríguez, A., Ferrer, A., García-Fuentevilla, L. L. and Eugenio, M. E. (2012).Biobleaching of pulp from oil palm empty fruit bunches with laccase and xylanase, Bioresource Technology 110, 371-378.

[22] Velásquez, J. A., Ferrando, F. and Salvadó, J. (2002). Binderless fiberboard from steam exploded Miscanthus sinensis: The effect of a grinding process, European Journal of Wood and Wood Products 60(4): 297-302.

[23] Sgriccia, N., Hawley, M.C and Misra, M. (2008) Characterization of natural fiber surfaces and natural fiber composites, Composites: Part A 39: 1632-1637.

[24] Sotannde, O.A., Oluwadare, A.O., Ogedoh, O. and Adeogun, P.F. (2012) Evaluation of cement-bonded particle board produced from Afzelia africana wood residues J.Eng.Sci. and Technol. 7(6): 732 - 43.

[25] Lee. H.H. and Kang, C.W. (1998) Development of rice hull insulation board using urea formaldehyde resin, Journal of Korean Wood Science and Technology. 26(4):50-55.

[26] Kokandeh, M.G. (2013). Effect of Acetylation on Heat Transfer Mechanism During Hot Pressing and Mechanical Properties of Wood Based Composites, Lignocellulose, 2(1): 307-315. 307

\section{Author' biography with Photo}

Dr. B.O. Ogunsile is a Senior Lecturer at the University of Ibadan, Nigeria. He holds a Ph.D. degree in Industrial Chemistry from the University of Ibadan, Nigeria. His research interests are in the areas of utilization of tropical fibers for pulp, paper, effluent detoxification and polymer and cement/fiber composite production.

Mr. R. Saheed, is a graduate of Chemistry at the University of Ibadan, Nigeria. He holds a B.Sc. in Industrial Chemistry.

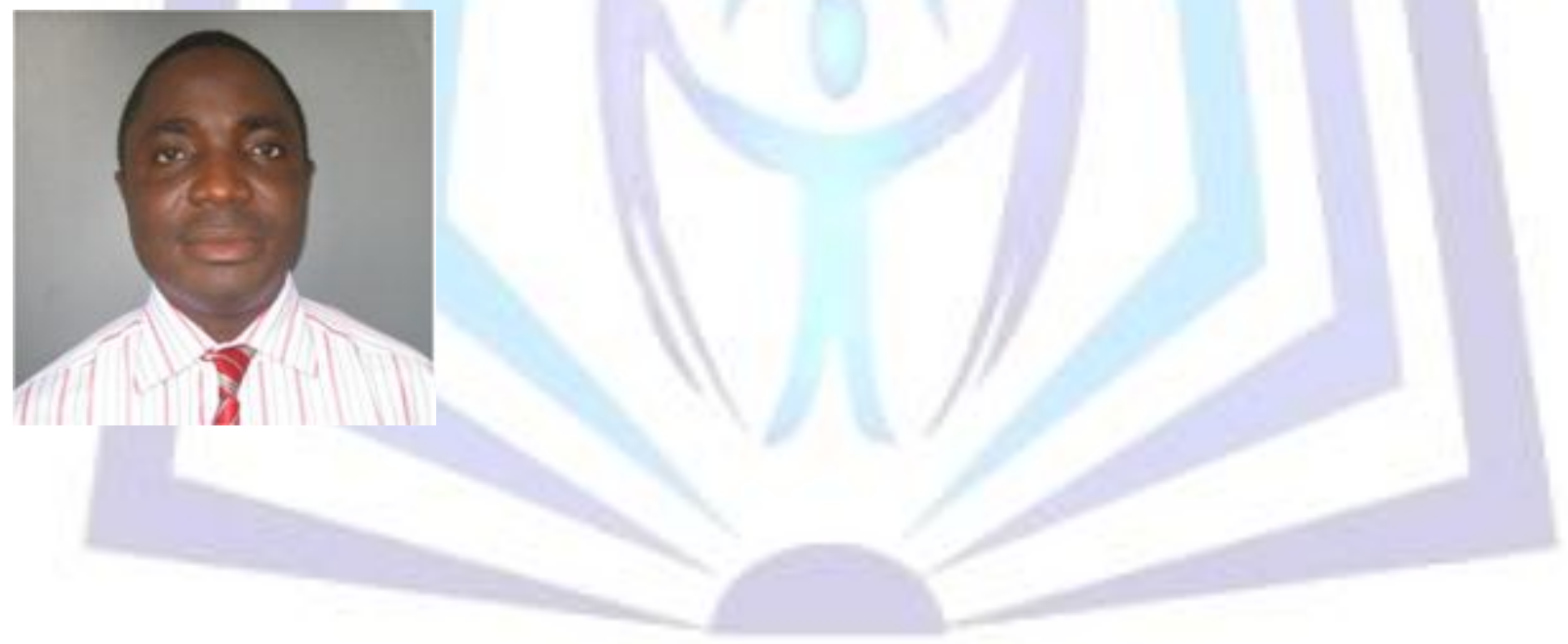

